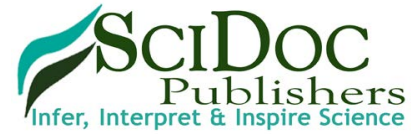

\section{Malignant Thyroid Teratoma with Neuroectodermal Component: A Case Report}

Villacrés Montesdeoca $\mathrm{LD}^{1 *}$, Villacrés $\mathrm{F}^{2}$, Muñoz $\mathrm{R}^{3}$

${ }^{1}$ Post-Degree of Clinical Oncology Hospital Oncológico Solón Espinosa Ayala, Central University of Ecuador, Quito, Ecuador.

${ }^{2}$ Resident Physician of the Teaching Hospital of Calderón Quito, Ecuador.

${ }^{3}$ Clinical Oncologist, Clinical Oncology Service, Hospital Oncológico Solón Espinosa Ayala, Ecuador.

\title{
Abstract
}

Malignant thyroid teratoma comprises a rare disease with a poor prognosis in the adult patient; we report the case of a 38-year-old male patient with rapidly growing neck mass undergoing thyroidectomy without lymph node emptying with a pathological report of malignant thyroid teratoma with a neuroectodermal component that was treated with chemotherapy and radiotherapy. After 12 months of follow-up, the patient remains stable and there is no relapse of disease. This is the first case to our knowledge of Malignant Thyroid Teratoma with neuroectodermal component in Ecuador.

Keywords: Thyroid; Teratoma; Neuroectodermal; Tumor; Ecuador.

\section{Introduction}

Teratomas is defined by the presence of tissue from any of the three primordial germ layers and are mainly found in the gonads; and when it develops extragonadal it is often found in the midline [1].

The majority of malignant teratomas that involve the thyroid are relatively rare in adults, being more frequent its presentation in children and of these the great majorities are benign [2].

To our knowledge, this is the first case of malignant thyroid teratoma with a neuroectodermal tumor component reported in Ecuador.

\section{Case Report}

A 38-year-old male patient that presented a history of 2-month of a rapid growth of tumor mass dependent on the right side of the neck, measuring at a physical examination of $6.5 \times 3.5 \mathrm{~cm}$; no significant family or personal pathological background.

He underwent total thyroidectomy finding a tumor mass corresponding to the right lobe of $9.5 \times 7 \times 6 \mathrm{~cm}$, lymphovascular and perineural invasion absent, 4 nodes were isolated, all absent of tumor activity; the malignant germinal neoplasm is constituted by extensive neuroectodermal areas with glia, neural structures (more than 3 fields), which are demonstrated with stains for PGFA (glial fibrillary acidic protein); areas of mesenchyme, immature muscle and focal areas with differentiation to Saco of Yolk (alpha fetus protein positive), concluding as malignant thyroid teratoma with neuroectodermal component.

Immunohistochemistry: glial fibrillary acidic protein: positive, enolase, s100, AFP, myod1: positive ki-67: 50\%.

Body tomography was requested 15 days after surgery, reporting negative for tumor activity, AFP: negative.

One month after having undergone surgery, chemotherapy treatment was started with a BEP scheme (bleomycin 30mg day 1 with reinforcement on days 8 and 15 , cisplatin $20 \mathrm{mg} / \mathrm{m} 2$ day 1 to 5 , etoposide $100 \mathrm{mg} / \mathrm{m} 2$ day 1 to 5 ) completing this scheme four cycles every 28 days.

After having concluded the chemotherapy sessions, the patient received intensity-modulated radiotherapy (IMRT) of 46 Gys and treated volume included the thyroid bed and cervical lymph nodes.

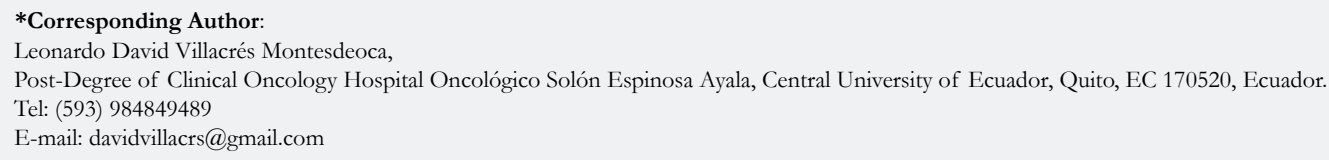

Citation: Villacrés Montesdeoca LD, Villacrés F, Muñoz R. Malignant Thyroid Teratoma with Neuroectodermal Component: A Case Report. Int J Cancer Stud Res. 7(2), 137-138. doi: http://dx.doi.org/10.19070/2167-9118-1800025

Copyright: Villacrés Montesdeoca $\mathbf{L D}^{\circ}$ 2018. This is an open-access article distributed under the terms of the Creative Commons Attribution License, which permits unrestricted use, distribution and reproduction in any medium, provided the original author and source are credited. 
There was no need for dose reduction during chemotherapy and colony stimulating factors were used during the treatment, at the end of the radiotherapy presented grade 2 mucositis.

The patient remains in a disease-free period for 12 months.

\section{Discussion}

Malignant thyroid teratoma is an aggressive tumor with a median survival of 8 months with surgical treatment only and an approximate report of 30 cases worldwide $[1,2]$ being Jarayam who describes a case of survival 15 months after surgery only; It should be emphasized that, since the BEP scheme is the one most used for those who have documented this treatment, we have opted as the most favorable option for our patient $[3,4]$.

Chen J. describes his experience in 1998 reporting a case of malignant thyroid teratoma treated with a BEP scheme, presenting a disease-free survival of 6.5 years, without the use of radiotherapy [5-8].

Richard W. describes as an aggressive treatment using cisplatin in the BEP scheme, immediately after surgery, based on similar studies in Afro descendant women in the studies of Kimler, Muth and Ueno $[2,3,9]$.

The role of Radiotherapy has often been discussed by entering into a line between whether or not there is a benefit according to several experiences, we have chosen to use IMRT radiotherapy because there was no correct lymph node emptying [10].

At the moment, the patient present an ECOG 0, remains in quarterly controls and was considered as a possible second line of treatment the P6 scheme described by Kushner in which cyclophosphamide, doxorubicin and vincristine were used, with patients with a complete response of up to 36 months $[2,11]$.

\section{Conclusion}

We consider that surgery should be a primary treatment accompanied by lymph node emptying as described in most of the literature of this disease and the use of Radiotherapy should be considered in the absence of surgical lymph node emptying, more studies of case reviews should be carried out in order to determine the best first line treatment scheme in this disease, however in this patient the BEP scheme has been well tolerated, presenting a clinical response.

\section{References}

[1]. Grewal AK, Wartofsky L, Kumar D, Chia SH. Malignant Thyroid Teratoma. AACE Clinical Case Reports. 2016 Sep;2(4):e284-289.

[2]. Kim E, Bae TS, Kwon Y, Kim TH, Chung KW, et al. Primary malignant teratoma with a primitive neuroectodermal tumor component in thyroid gland: a case report. J Korean Med Sci. 2007 Jun;22(3):568-71. PubMed PMID: 17596674

[3]. Vilallonga R, Zafon C, Ruiz-Marcellan C, Obiols G, et al. Malignant thyroid teratoma: report of an aggressive tumor in a 64-year-old man. Endocr Pathol. 2013 Sep;24(3):132-5. PubMed PMID: 23702575.

[4]. Thompson LD, Frommelt RA, Rosai J, Heffess CS. Primary thyroid teratomas: A clinicopathological study of 30 cases. Cancer. $2000 \mathrm{Mar}$ 1;88(5):1149-58. PubMed PMID: 10699906.

[5]. Chen BB, Yeh CC, Chang TC, Hsiao CH, Chen KY, Liu KL. Computed tomography diagnosis of primary thyroid teratoma. J Formos Med Assoc. 2005 Jul;104(7):514-7. PubMed PMID: 16091830.

[6]. Chen JS, Lai GM, Hsueh S. Malignant thyroid teratoma of an adult: a longterm survival after chemotherapy. Am J Clin Oncol. 1998 Apr;21(2):212-4. PubMed PMID: 9537215.

[7]. Craver RD, Lipscomb JT, Suskind D, Velez MC. Malignant teratoma of the thyroid with primitive neuroepithelial and mesenchymal sarcomatous components. Ann Diagn Pathol. 2001 Oct;5(5):285-92. PubMed PMID: 11598856.

[8]. Tsang RW, Brierley JD, Asa SL, Sturgeon JF. Malignant teratoma of the thyroid: Aggressive chemoradiation therapy is required after surgery. Thyroid. 2003 Apr;13(4):401-4. PubMed PMID: 12804109.

[9]. Ueno NT, Amato RJ, Ro JJ, Weber RS. Primary malignant teratoma of the thyroid gland: report and discussion of two cases. Head Neck. 1998 Oct;20(7):649-53. PubMed PMID: 9744468.

[10]. Ramadas K, Augustin J, Parameswaran S, Joseph F. Malignant teratoma in the thyroid gland. The British journal of radiology. 1996 Sep;69(825):87980 .

[11]. Rabinowits G, Barletta J, Sholl LM, Reche E, Lorch J, Goguen L. Successful Management of a Patient with Malignant Thyroid Teratoma. Thyroid. 2017 Jan;27(1):125-128. PubMed PMID: 27784193. 